\title{
Teachers' perception about genes and behavior
}

\author{
Percepção docente sobre genes e comportamentos
}

\author{
Mayra ANTONELLI-PONTI' (iD) 0000-0003-4931-2788 \\ Fabiana Maris VERSUTI ${ }^{2}$ iD 0000-0002-3504-4842 \\ José Aparecido DA SILVA2 (D) 0000-0002-1852-369X
}

\begin{abstract}
Knowing about teacher perceptions contributes to the understanding of teachers' attitudes toward the behavior of their students. We evaluated the perceptions of 501 teachers about the genetic and environmental influences on behaviors considered relevant to the educational environment using an original questionnaire from the United Kingdom, adapted to the Portuguese language of Brazil. We found that the teachers attributed genetic and environmental influences evenly regarding personality and learning difficulties; greater genetic influence on intelligence and mental illness; and greater environmental influence on behavioral problems. Most teachers stated that having a student with genetically influenced learning difficulties would affect their method of instructing them.
\end{abstract}

Keywords: Educational environment; Behavior; Genes; Social perception; School teachers.

\section{Resumo}

Conhecer a percepção docente colabora para compreender as atitudes do professor diante do comportamento de seus alunos. A percepção de 501 professores acerca da influência genética e ambiental sobre comportamentos considerados relevantes no ambiente educacional foi avaliada por meio de um questionário original do Reino Unido, adaptado à língua

1 Universidade de São Paulo, Faculdade de Filosofia, Ciências e Letras de Ribeirão Preto, Programa de Pós-Graduação em Psicobiologia. Av. Bandeirantes, 3900, Monte Alegre, 14040-901, Ribeirão Preto, SP, Brasil. Correspondência para/Correspondence to: M. ANTONELLI-PONTI. E-mail: <antonelli.may@gmail.com>.

2 Universidade de São Paulo, Faculdade de Filosofia, Ciências e Letras, Departamento de Psicologia. Ribeirão Preto, SP, Brasil.

Article based on the master's thesis of M. ANTONELLI-PONTI, entitled "Teachers' perceptions about genetic and environmental influence on relevant behaviors in the educational process". Universidade de São Paulo, 2016.

Support: Conselho Nacional de Desenvolvimento Cientifico e Tecnologico for the period from 2014 to 2016 (grant no 132355/2014-0).

Acknowledgement: The authors wish to thank Conselho Nacional de Desenvolvimento Científico e Tecnológico for financial support, Professor Davi Casale Aragon for statitical assistance, and the techers who participated in the research.

Como citar este artigo/How to cite this article

Antonelli-Ponti, M., Versuti, F. M., \& Da Silva, J. A. (2018). Teachers' perception about genes and behavior. Estudos de Psicologia (Campinas), 35(4), 421-431. http://dx.doi.org/10.1590/1982-02752018000400009 
portuguesa do Brasil. Os professores apontaram: equilibrio de influências genéticas e ambientais sobre a personalidade e as dificuldades de aprendizagem; maior influência genética sobre a inteligência e as doenças mentais; e maior influência ambiental sobre os problemas de comportamento. A maioria dos professores declarou que ter um aluno com dificuldade de aprendizagem geneticamente influenciada afetaria seu método de instruí-lo.

Palavras-chave: Ambiente educacional; Comportamento; Genes; Percepção social; Professores escolares.

How people perceive themselves and others influences how they react to the behaviors of people in general (Alves, Batista, Ribeiro, \& Érnica, 2015; Bank, 2015; Moore, 2013; Osti \& Martinelli, 2014). Indeed, perceptions about the origins of behaviors, of factors that influence development and contribute to the determination of behavioral differences among individuals (Moore, 2013), may lead to the elaboration of positive or negative judgments, thus representing a relevant dimension in social life, including the educational process (Luckesi, 2011). As two researchers assert:

Among the different possibilities of interpersonal relations in the classroom, it can be seen that the formation of expectations and perceptions by the parties involved permeates any type of established relationship. Thus, teachers base their attitudes on the perception and expectations they have about their students (Martinelli \& Schiavoni, 2009, p.328).

Intelligence, personality, learning difficulties, behavioral problems, and mental diseases are characteristics or conditions that will be referred to here as behaviors, since they express conduct. These behaviors are considered relevant to the educational environment (Walker \& Plomin, 2005), and were taken as the basis of the present investigation. However, many other behavioral factors, such as self-discipline, organization, sense of duty, and curiosity are known to have an impact on the teaching and learning process as well (Poropat, 2009).

The nature versus nurture perspective reflects how genes and environment influence the display of such behaviors, or interact in their expression, as well as in the development of individuals (Haworth, Davis, \& Plomin, 2013; Moore, 2013; Ridley, 2004). The nature versus nurture debate is a long-standing one: could our skills be inborn components, or are our minds blank slates at birth (Pinker, 2002), to be filled out by means of contact with the external world?

Arguments that consider only one of the factors are a source of concern, and are seen as fallacious (Ackerman, 2014). For example, Pinker (2002) refutes exclusively environmental positions, while Ridley (2004) advances a new proposal for the term, replacing versus with via (nature via nurture). Studies of epigenetic markers have demonstrated that genes are activated or deactivated depending on the environment, with changes in their expression, and in the resulting phenotype (Carey, 2011). Currently established knowledge can contribute to various areas, including the educational field (Asbury \& Plomin, 2013; Plomin, DeFries, Knopik, \& Neiderhiser, 2016).

However, there is no evidence that these advances have been incorporated into people's perceptions of other people in general. Parents' reports about the performances of their children reveal a lack of knowledge about aspects related to the role of genes in intelligence, since parents who recognize that their children were not successful in school do not understand how they could perform well in it (Chechia \& Andrade, 2005).

The report "Repensando a escola: um estudo sobre os desafios de aprender, ler e escrever" (Rethinking school: a study of the challenges of learning, reading and writing) of the United Nations Educational, Scientific, and Cultural Organization (Unesco) (Ireland, 2007) compiles the opinions of teachers about the teaching-learning process, and shows that most of them attribute to the students themselves the responsibility for being promoted or not. This document presents facets of teachers' perceptions of common sense, such as the notion of being gifted (or natural endowment), which some may have and others may not, and how that could 
define school performance. This naturalizing view does not take into consideration the "ecological transitions" between the different contexts in which a person develops (Bronfenbrenner, 1996), however, and is clearly associated with erroneous beliefs about genetic influence on human behavior (Da Silva, 2005), considering that discoveries made on the basis of genetically sensitive investigative projects advocate the importance of the environment (Plomin et al., 2016).

Several investigations have been carried out to assess the perceptions of various social groups regarding questions related to genetics and behavior. Evaluations of the opinions of professionals in the area of educational psychology and education have revealed widespread acceptance of the role of genetics in people's intelligence (Snyderman \& Rothman, 1988). Indeed, it has been found that the public's perceptions of the general aspects of human genetics is based on a relatively balanced view of genetic and environmental factors (Human Genetics Commission, 2001).

The opinions of lay people about the existence of an underlying basis for social categories are called "essentialist beliefs", and seem to justify the existence of a determined social order (Keller, 2005). Moreover, Rattan, Savani, Naidu, and Dweck (2012) observed that perceptions of the people's potential for intelligence are related to political options. Additionally, a study conducted in different countries about the conceptions of teachers regarding genetic influences on human behavior demonstrated that they change according to nationality, to the development of a country, and to religious beliefs (Castéra \& Clément, 2014). For example, parents and teachers from the United Kingdom believe that genes and environment influence the behavior of their children and other students, but they attribute a greater influence to genetics regarding intelligence, personality, learning difficulties, and mental disorders. However, they attribute a greater influence to the environment regarding behavioral problems (Walker \& Plomin, 2005). More recently, Plomin, Shakeshaft, McMillan, and Trzaskowski (2014) emphasized the importance of assessments of perceptions among different parcels of society by stating that, if a survey were conducted in the academic medium, probably people belonging to all disciplines would overwhelmingly accept the importance of both genes and environment. This statement was confirmed by Rindermann, Becker, and Coyle (2016), who surveyed the opinions of the academic elite about the area of intelligence, and found that its perception of genetic influence is of a magnitude similar to the ensemble of various environmental influences, with emphasis on the quantity and quality of the education.

Regarding teacher perceptions, a less recent investigation (Brambilla \& Júlio, 1999) demonstrated that teachers attribute external causes, such as the school system and crowded classes, to the difficulties detected in the literacy process, rather than personal causes, such as their own competence. They attribute little importance, for example, to the stimuli provided to the students. As for genetic and environmental influences, it is important to mention that encouraging knowledge about genetic aspects does not exempt the responsibility and the role of education; however, it can be essential in delineating the uniquely important function of the school environment, and of the acceptance of unique perspective of each student (Luckesi, 2011). Taking into consideration the relevance of the variables related to the school environment permits the recognition of individual differences as opportunities for the creation and implementation of new teaching strategies, in order to cover classroom diversity, and thus provide effective forms for optimizing learning and assessment throughout the educational process (Asbury \& Plomin, 2013). Hence, understanding the interaction of genes and environment favors conditions that will lead the children to the complete fulfilment of their potential (Asbury \& Plomin, 2013).

The perceptions of Brazilian teachers about these questions are still unknown. Considering the scarcity of studies in the national context, the objective of this investigation was to analyze teachers' perceptions of how genes and environment influence the intelligence, personality, learning difficulties, behavioral problems, and mental 
disorders of students, in addition to their attitudes towards students with genetically influenced learning difficulties. We believe that this is relevant for obtaining similar information among the general Brazilian population, in order to understand if the attitudes of teachers are affected by the genetic conditions of their students, and to expand current knowledge about this aspect of social perceptions.

\section{Method}

A descriptive cross-sectional study was conducted from October, 2014, to October, 2015.

\section{Participants}

We selected a convenience sample according to subject locations close to the authors' institution. The number of participants was defined on the basis of previous studies in this research line (Castéra \& Clément, 2014; Walker \& Plomin, 2005). A total of 501 teachers in the public school network (65.0\%), and in the private network (35.0\%), of the state of São Paulo participated in the study. The sample predominantly consisted of women $(72.1 \%)$, and their mean age was 40 years (range: 22-67 years).

\section{Instruments}

The research instrument used in this study was a questionnaire originally applied to United Kingdom parents and teachers (Walker \& Plomin, 2005). In view of the differences in language and culture between there and Brazil, it underwent a process of adaptation, which was also part of the present study.

In addition to demographic data, the questionnaire contained the following seven questions: one about the training of the teacher, five containing multiple choice items and numerical scales for the assessment of teachers' perceptions of the genetic and environmental influences on relevant educational behaviors, and one about their attitudes on the presence of the genetic conditions of their students; it was also in a multiple choice format, with a numerical scale.
The five multiple choice questions used numbers like those on a Likert scale. The questions about genetic and environmental influences on each behavioral trait contained the following items: Only genes $=1$; More genes than environment $=2$; Genes and environment in equal parts $=3$; More environment than genes $=4$; Only environment $=5$. Mean values of about 1 indicate a perception that the trait is more influenced by genes, and mean values of about 5 indicate a perception that the trait is more influenced by the environment. The question about the teachers' attitudes on students' genetic endowments contained the following items: Would affect completely $=1$; Would affect a lot $=2$; Would affect in part $=3$; Would affect a little $=4$; Would not affect $=5$.

The numerical scales ranged from 0 to 10 , and measured the weight the teacher attributed to the genetic or the environmental influence on each behavior, and how much a genetically influenced difficulty in a student would affect their teaching methods.

Previous studies, including the ones that inspired the present investigation (Human Genetic Commission, 2001; Walker \& Plomin, 2005), have used the participants' responses as described above, with the mean representing the perception of the sample.

\section{Procedures}

\section{Adaptation of the questionnaire}

We followed the adaptation steps recommended by Borsa, Damásio, and Bandeira (2012) for the use of the questionnaire within the Brazilian context, i.e.: obtaining authorization from the authors of the original instrument; an English-Portuguese translation; evaluation of target public, 1) addition of the numerical scales, 2 ) opinion of specialists, and 3) a pilot study; and finally, back translation. After these steps, we collected the data, and determined the test-retest reliability.

The evaluations of the target public, the addition of numerical scales, and the opinions of 
the specialists were steps aimed at the appropriate presentation of items, words, sentences, and the questionnaire's format. We conducted the pilot study in order to obtain an understanding of the generated version, and of the instructions given at the beginning of application on the part of the target public. We sent the back translation of the final version to the original authors, who approved it. The questionnaire was found to be clear and understandable for the participants, and was also considered adequate for the target public. To determine the questionnaire's reliability, it was applied at two different times to parts of the sample. The Pearson correlation between the total mean score of the instrument in the first and second applications was $r=0.996$, demonstrating high reliability. Furthermore, according to the evaluation steps for the target public and the specialists' opinions, the questionnaire showed apparent validity. The results obtained with the application of the instrument were likewise found similar to those obtained in the original study, conferring convergent validity to the adapted instrument (Cohen, Swerdlik, \& Sturman, 2014).

\section{Data collection}

The principal investigator contacted teaching institutions in the State of São Paulo, mainly those of municipalities in its northwest, in order to obtain authorization for the application of the instrument. The institutions that agreed to collaborate with the investigation were selected.

For all applications, the teachers received the printed questionnaires and an informed consent form, with instructions about filling out the responses, and information about the objectives of the investigation.

The project was approved by the Research Ethics Committee for Studies on Human Beings at the authors' institution (Protocol $n^{\circ} 771.808$ ).

\section{Data analysis}

We analyzed descriptive analysis and differences in perceptions by the study's subjects regarding each behavior with the nonparametric Friedman test (variables do not form a normal distribution) for multiple mean comparisons, using International Business Machines Statistical Package for the Social Sciences (IBM SPSS Inc., Chicago, IL, EUA) 19.0 software for Windows. We then applied correspondence analysis for group comparison in terms of Sex, Age, Schooling, Area of Knowledge, Income, Time of Activity, Knowledge of Genetics, and Having Studied Genetics, using the Statistical Analysis System (SAS, North Carolina State University, EUA) software version 9.3. We performed this analysis using the items of the multiple choice questions, and considered all behaviors. The closer the variables on the map, the more frequent their joint occurrence.

\section{Results}

Approximately half $(49.7 \%)$ of the participants declared that they had studied genetics during their training as teachers, and most (69.5\%) reported some knowledge about genetic influence on human behavior, mainly obtained from books, TV documentaries, the internet, and magazines.

We filled out the numerical scales by attributing substantial influences to these two factors. For personality and behavioral problems, the highest percentages of the responses fell between numbers 7 to 10 on the environment scale. For intelligence, learning difficulties, and mental disorders, the highest percentages of the responses fell between numbers 7 and 10 on the genetic scale.

The multiple choice questions regarding personality and behavioral problems obtained a mean value of above 3 ; intelligence and learning difficulties obtained a mean value of below 3 ; and mental disorders obtained a mean value of below 2 , indicating perception of a greater genetic influence (Table 1). Significantly, comparison of the sample for each behavior using multiple choice questions revealed statistically significant differences $(p=0.00)$.

In general, the sample groups were more associated with items containing the genetic factor; the item "only environment" (IGA5) was 
Table 1

Percentage of responses per item, mean, and standard deviation of responses from 1 to 5 about genetic and environmental influences on the listed behaviors

\begin{tabular}{|c|c|c|c|c|c|c|c|}
\hline & Only genes 1 & $\begin{array}{c}\text { Genes > } \\
\text { environment } 2\end{array}$ & $\begin{array}{c}\text { Genes = } \\
\text { environment } 3\end{array}$ & $\begin{array}{c}\text { Genes < } \\
\text { environment } 4\end{array}$ & $\begin{array}{c}\text { Only } \\
\text { environment } 5\end{array}$ & Mean & $S D$ \\
\hline Personality & $1.20 \%$ & $19.70 \%$ & $40.60 \%$ & $38.20 \%$ & $0.40 \%$ & 3.17 & 0.79 \\
\hline Intelligence & $8.20 \%$ & $43.60 \%$ & $31.70 \%$ & $15.70 \%$ & $0.80 \%$ & 2.57 & 0.88 \\
\hline Learning difficulties & $2.60 \%$ & $33.90 \%$ & $35.10 \%$ & $27.40 \%$ & $1.00 \%$ & 2.9 & 0.87 \\
\hline Behavioral problems & $0.60 \%$ & $9.30 \%$ & $28.40 \%$ & $58.10 \%$ & $3.60 \%$ & 3.55 & 0.73 \\
\hline Mental disorders & $38.40 \%$ & $47.90 \%$ & $11.50 \%$ & $2.00 \%$ & $0.20 \%$ & 1.78 & 0.74 \\
\hline Total & $10.20 \%$ & $30.88 \%$ & $29.45 \%$ & $28.27 \%$ & $1.20 \%$ & 2.79 & \\
\hline
\end{tabular}

Source: Reproduced from Antonelli-Ponti (2016).

Note: SD: Standard Deviation.

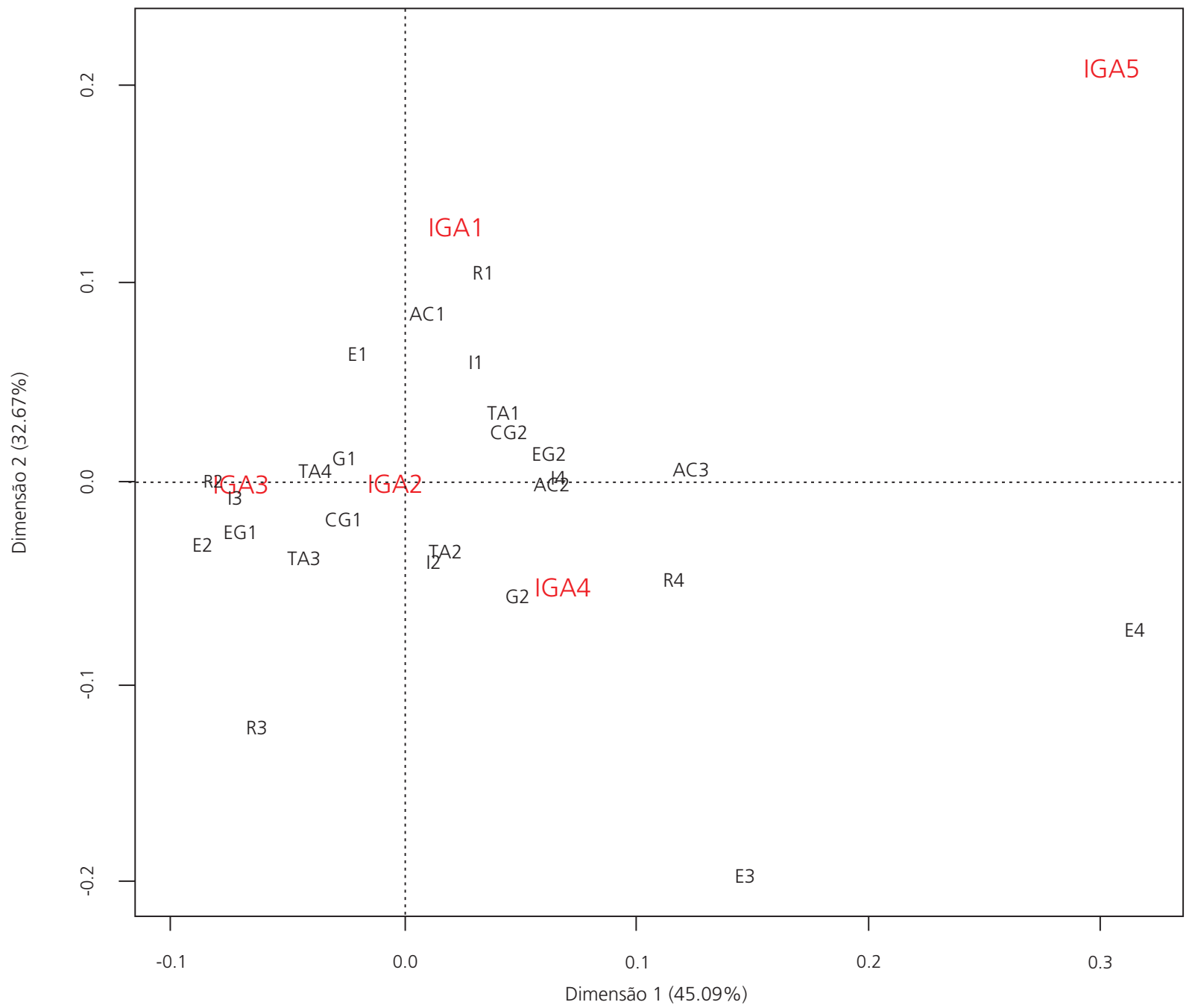

Figure 1. Correspondence analysis of multiple choice items regarding the genetic and environmental influences on behavior relevant to the educational process and sample subgroups.

Note: IGA1: Only genes; IGA2: More genes than environment; IGA3: Genes and environment in eqal parts; IGA4: More environment than genes; IGA5: Only environment; G1: Female; G2: Male; AC1: Human sciences; AC2: Biological sciences; AC3: Exact sciences; EG1: Studied genetics; EG2: Did not study genetics; CG1: Knows genetics; CG2: Does not know genetics; E1: Complete higher education; E2: Complete higher education with specialization; E3: Master's degree; E4: Doctorate and postdoctoral training; R1, R2, R3 and R4: Income ranges in increasing order; I1, 12, 13 and 14: Age ranges in increasing order; TA1, TA2, TA3 and TA4: Times of activity in increasing order. 
not associated with the sample groups. The items containing the genetic factor were associated with one another, and with most of the sample groups, demonstrating great acceptance of genetic influence on all behaviors. Meanwhile, the area of knowledge (AC) groups yielded a counterintuitive result: the "human sciences" (AC1) was closer to "genes only" (IGA1), and the biological and exact science areas (AC2 and AC3) were closer to "more environment than genes" (IGA4). The income ranges, for their part, formed an association gradient: the lower the income ( $R 1$ and $R 2$ ), the greater the perception of genetic influence, whereas with increasing income (R4) there was a growing perception of the environmental influence.

Women (G1) were associated with the item "more genes than environment" (IGA2), and men (G2) were associated with the item "more environment than genes" (IGA4). Regarding educational level, the groups with "higher education" and "specialization" (E1 and E2) were closer to the items "genes only" (IGA1), "more genes than environment" (IGA2), and "genes and environment in equal parts" (IGA3). Finally, the "master's" and "doctorate or postdoctoral" groups (E3 and E4) were not associated with any item. (Figure 1).

Most of the teachers evaluated (93.8\%) declared that being aware of a genetically influenced learning difficulty in one of their students would affect their method for the instruction and monitoring of this student (Figure 2). The numerical

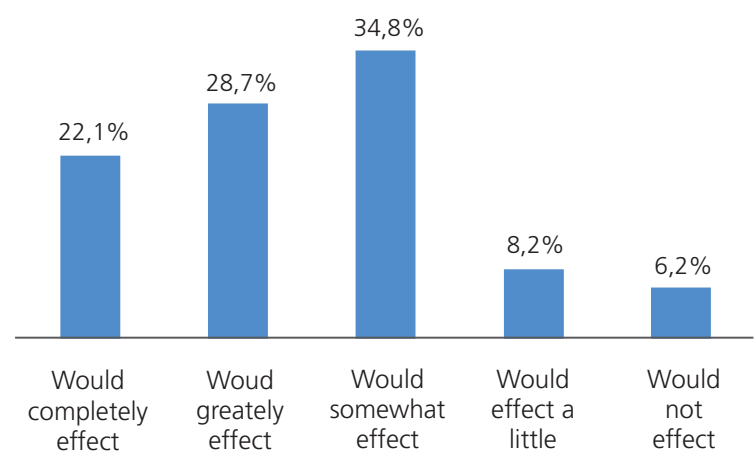

Figure 2. Percentage of teachers' responses to the statement, "Would knowing that a student has genetically influenced learning difficulties affect your method of instructing and monitoring them?" (Antonelli-Ponti, 2016). scale for the extent to which the teacher's methods would be affected showed that $92.6 \%$ of the participants assigned numbers from 4 to 10 .

\section{Discussion}

This study analyzes the perceptions of teachers about how genes and environment influence intelligence, personality, learning difficulties, behavioral problems, and mental disorders, as well as their attitudes toward students with genetically influenced learning difficulties.

For the multiple choice questions, considering that item three represents the equivalent influence of genes and environment on behaviors, the mean values indicated that teachers perceived genetic and environmental influences in a balanced manner for Personality $(3.17 ; S D=0.79)$ and Learning difficulty (2.90; $S D=0.87)$, and attributed a greater genetic influence to Intelligence $(2.57 ; S D=0.88)$ and to Mental Disorders (1.78; $S D=0.74)$, along with a greater environmental influence on Behavioral Problems (3.55; $S D=0.73)$. The statistically significant difference between mean perception values demonstrates that teachers recognized the fact that each behavior has a dynamic of genetic and environmental influences (Asbury \& Plomin, 2013).

Jointly considering the mean for all behaviors (2.79), it can be seen that the perception of genetic influence is slightly higher, although it is close to equilibrium between factors (Table 1). This general mean agrees with two previous studies: a survey of public attitudes toward human genetics, in which the ensemble of the mean values for an ample gamut of characteristics gave a result of 2.69 (Human Genetics Commission, 2001); and the study that inspired this one (Walker \& Plomin, 2005), in which parents and teachers in the United Kingdom responded to the same questions as those we asked, with a general mean of 2.57 for the parents' responses, and of 2.66 for the teachers'. These results provide information about similar perceptions of genetic and environmental influences on different groups at different time points: participants in the investigations by Snyderman and Rothman (1988), and Rindermann 
et al. (2016), considered a predominantly genetic influence on the difference in intelligence without ruling out the various environmental factors, and emphasized the importance of the educational environment. The perceptions of the present sample are close to recent discoveries that have detected a substantial genetic influence with the essential role of the environment on human characteristics and complex behaviors (Plomin et al., 2016; Polderman et al., 2015; Wesseldijk et al., 2017).

This view of the importance of these two factors does not hide the fact that a much greater parcel of the sample believed in gene exclusivity compared to the exclusive role of the environment. Considering the responses to the five behaviors together, $10.20 \%$ of the teachers chose the option "only genes", while $1.20 \%$ chose the option "only environment". These extreme positions are seen as nonsense by recent researchers (Ackerman, 2014). This is mainly because attributing individual success or failure only to the environment does not explain the reason why individuals are different, even when submitted to an identical environment (Ackerman, 2014). Failure to consider the role of genes is to deny human nature itself, as well as the entire evolutionary history inserted into our genes up to the time of conception, followed by the interactions of the genes with all possible stimuli throughout life (Pinker, 2002; Wesseldijk et al., 2017).

On the other hand, without their environment, the genes have no influences: genes respond to the environment in the phenomenon of geneenvironment interaction, and the environment responds to the genes in gene-environment correlations (Briley \& Tucker-Drob, 2014; Plomin et al., 2016; Tucker-Drob \& Briley, 2014). The belief of trait immutability, meanwhile, can influence important decisions, such as opposition to public policies for containing social inequality (Rattan et al., 2012). Thus, a belief in biological determinism, as observed in research on teachers from different countries, is related to creationistic conceptions (Castéra \& Clément, 2014), and explains intolerant attitudes regarding differences between groups (Castéra \& Clément, 2014, Keller, 2005). In the educational environment, a belief in genetic determinism as fatalistic and immutable can influence the perception that student behavior cannot be changed (Ireland, 2007).

Therefore, acquiring knowledge about genetic influences and mechanisms can modify assumptions and myths about genetic determinism, such as trait immutability (Kampourakis, Reydon, Patrinos, \& Strasser, 2014), and contributes to an understanding of individual behavioral differences that recognizes human nature not as an alternative to creation, but as an explanation, thus encouraging the search for the limits of a human being (Asbury \& Plomin, 2013; Da Silva, 2005). As one researcher stated, "It is difficult to educate when we do not believe in the educability of each human being, and therefore the idea of a gift symbolizes giving up education and trying again despite previous failures" (Ireland, 2007, p.30).

Importantly, behaviors involving cognition, such as Intelligence and Learning Difficulties, showed a higher percentage of responses directed at genetics (51.8\% for Intelligence, and 36.5\% for Learning Difficulties). In contrast, domains involving social behaviors, such as Personality and Behavioral Problems, showed higher percentages of responses directed at the environment (38.6\% for Personality, and $61.7 \%$ for Behavioral Problems) (Table 1).

When investigating teacher-student interaction and the students' perceptions regarding teacher expectations, Osti and Martinelli (2014) observed that students with a satisfactory performances declared that they were more praised and chosen as helpers, whereas students with unsatisfactory performances declared that they were more criticized and considered guilty when some undisciplined event occurred in the classroom. In the light of behavioral genetics, the occurrence of a reactive or evocative gene-environment interaction is notable here, with the genetic predisposition of the students evoking specific behaviors from the persons around them (Plomin et al., 2016), in this specific case, the teacher. It has been found that any predisposition to behavioral traits is susceptible to environmental stimulation (Briley \& Tucker-Drob, 2014; Plomin et al., 2016), especially considering the importance of an environment that is not 
shared, i.e., the specific environmental influence for each individual, which has a specialized influence (Tucker-Drob \& Briley, 2014).

Both the student's propensity to a given behavior and the teacher's perception of it contribute to the way the teacher deals with this student. Considering the results of the cited study (Osti \& Martinelli, 2014) together with the present ones, we may argue that perceiving a greater genetic influence on behaviors related to cognition may be linked to the belief in the immutability of traits, leading to a harmful reaction to differences in student performance.

However, the diversity of the teachers' responses demonstrates that their perceptions are distributed along a continuum, not simply at two opposite points. The same occurs with the social perception of beliefs about the genetic and environmental influence on intelligence, and on its malleability or immutability, and about brain development and plasticity throughout life (Thomas \& Sarnecka, 2015). More importantly, most teachers $(88.57 \%)$ selected the options that consider the influence of the two factors in certain proportions (Table 1).

Correspondence analysis (Figure 1) showed that women (G1) perceive genes as having more influence on behavior (IGA2), and that men (G2) perceive the environment as having more influence (IGA4), confirming the results reported by the study of the Human Genetics Commission (2001). The same analysis showed that higher educational levels (E3 and E4) turned more towards the environmental side of the map, while lower levels (E1 and E2) were close to items representing perceptions of a predominance of genetic influence. There are similarities between these results and those of Cástera and Clément (2014), who observed that the higher the teachers' educational levels, the lower the innate aspect detected in their responses.

Multiple choice questions further limit the teachers' perceptions to an additive model of influences, by dividing the items into genetic and environmental portions, even in the item "genes and environment in equal parts," which assigns $50.0 \%$ of the influence to the genes, and $50.0 \%$ to the environment. Analysis of the numerical scales, however, revealed that some of the teachers did not fill out the numeration of the scales in a complementary manner, but instead with equal or close numbers. According to this model, it can be seen that in $2.15 \%$ of cases, a value of 10 was assigned to the two scales-genetics and environment-with overlapping of item three ("genes and environment in equal parts"). This demonstrates that the teachers not only consider the influence of genes and environment, but also that they perceive the interaction between genes and environment as non-additive, or rather as interactive, to the point that they assigned the same weight to the two factors, i.e., "100.0\% genetic and $100.0 \%$ environmental" (Jacquard \& Kahn, 2001, p.167).

Meanwhile, in the teachers' responses to the question of how much their teaching methods would be affected if they knew that the learning difficulty of a student is genetically influenced, $93.8 \%$ of them declared that this condition would affect in some measure their attitudes towards the student (Figure 2). The numerical scale showed that $92.6 \%$ of the teachers declared that the measure for a change in attitude would be equal to or higher than 4 on a scale from 0 to 10 , with $50.0 \%$ of them assigning weights from 7 to 9 . This study evaluates Brazilian teachers of all educational levels, most of whom declared that they acted on different levels at the same time. Interestingly, these results are closely similar to those reported by Walker and Plomin (2005) in a United Kingdom study, in which $82.0 \%$ of teachers of seven-year-old pupils, with the presence of twins in the classroom, declared completely or somewhat true the statement "Knowing that a student has a genetically influenced learning difficulty, would this affect your method of instructing and monitoring him." This discovery confirms the thesis that having some type of perception about an individual affects one's way of acting towards him (World Bank Group, 2015; Moore, 2013). As if following positive feedback, the teacher diversifies his teaching strategies when learning about the peculiarities of the student, thus expecting the student to improve his performance. 
In general, teachers' perceptions about genetic and environmental influences on the behaviors investigated is similar to the discoveries of the genetics of human development. In addition, most teachers perceived genetic patrimony and environmental as influencing in some manner the behavior of their students, and that their own teaching methods are affected because of knowing about the genetically influenced learning difficulties of some students. The percentage of perceptions exclusively directed at genetic or environmental influence was small, demonstrating erroneous beliefs in genetic and environmental determinism, although this result demonstrates that this perception is considered to be valid by only some teachers.

Knowing how human behaviors develop throughout life, and how they are influenced by genetic and environmental factors, is essential for a complete comprehension of society (Wesseldijk et al., 2017), and even for the formulation of public policies, and the effective implementation of efficient educational systems (Asbury \& Plomin, 2013). Finally, a bioecological analysis of the environments into which subjects are inserted permits an integrated understanding of these phenomena, as well as an understanding of how teachers' perceptions of a determined academic behavior by their students can influence the future psychological behavior of the students, and their interpersonal relationships (Bronfenbrenner, 1996).

\section{Final Considerations}

Since perceptions are not sufficient in themselves to plan an action about a given situation, this paper's recommendation is to invest in continuing education courses, or to include, within possible limits, in teacher training curricula, or in already existing disciplines, studies on human behavioral genetics with cognitive and behavioral development, emphasizing behaviors that are educationally relevant.

These proposals intend to provide teachers with the framework necessary for optimizing the educational process, since, even though all behaviors are genetically influenced, an environment containing a wealth of good stimuli will have positive effects on the students' educational performances, and will contribute to their development as fulfilled and productive citizens in society.

\section{Contributors}

M. ANTONELLI-PONTI principal author, conception and design of the project, adaptation of the questionnaire, data collection, literature review, analysis and interpretation of the data, writing the final version of the paper. F.M. VERSUTI literature review, data interpretation, revision of the text and of the final version of the paper. J.A. SILVA adviser of the Master's thesis of M. ANTONELLI-PONTI.

\section{References}

Ackerman, P. L. (2014). Nonsense, common sense, and science of expert performance: Talent and individual differences. Intelligence, 45(1), 6-17. http://dx.doi. org/10.1016/j.intell.2013.04.009

Alves, L., Batista, A. A. G., Ribeiro, V. M., \& Érnica, M. (2015). Seleção velada em escolas públicas: práticas, processos e princípios geradores. Educação e Pesquisa, 41(1), 137-152.

Antonelli-Ponti, M. (2016). Percepção de professores sobre a influência genética e ambiental em comportamentos relevantes no processo educacional (Dissertação de mestrado não-publicada). Universidade de São Paulo, Ribeirão Preto.

Asbury, K., \& Plomin, R. (2013). G is for genes: The impact of genetics on education and achievement (Vol. 24). Chichester: John Wiley and Sons.

Borsa, J. C., Damásio, B. F., \& Bandeira, D. R. (2012). Adaptação e validação de instrumentos psicológicos entre culturas: algumas considerações. Paidéia, 22(53), 423-432.

Brambilla, L. H., \& Júlio, A. A. (1999). Percepção do professor sobre o processo de alfabetização. Estudos de Psicologia (Campinas), 16(2), 28-36.

Briley, D. A., \& Tucker-Drob, E. M. (2014). Genetic and environmental continuity in personality development: A meta-analysis. Psychological Bulletin, 140(5), 1303. http://dx.doi.org/10.1037/a0037091

Bronfenbrenner, U. (1996). A ecologia do desenvolvimento humano: experimentos naturais e planejados. Porto Alegre: Artes Médicas.

Carey, N. (2011). The epigenetics revolution: How modern biology is rewriting our understanding of genetics, disease and inheritance. London: Icon Books. 
Castéra, J., \& Clément, P. (2014). Teachers' conceptions about the genetic determinism of human behaviour: A survey in 23 countries. Science and Education, 23(2), 417-443.

Chechia, V. A., \& Andrade, A. D. S. (2005). O desempenho escolar dos filhos na percepção de pais de alunos com sucesso e insucesso escolar. Estudos de Psicologia (Natal), 10(3), 431-440.

Cohen, R. J., Swerdlik, M. E., \& Sturman, E. D. (2014). Testagem e avaliação psicológica. Porto Alegre: Artmed.

Da Silva, J. A. (2005). Inteligência: resultado da genética, do ambiente ou de ambos? Ribeirão Preto: Lovise.

Haworth, C. M., Davis, O. S., \& Plomin, R. (2013). Twins Early Development Study (TEDS): A genetically sensitive investigation of cognitive and behavioral development from childhood to young adulthood. Twin Research and Human Genetics, 16(01), 117-125.

Human Genetics Commission. (2001). Public attitudes to human genetic information: People's panel quantitative study conducted for the Human Genetics Commission. London: Human Genetics Commission.

Ireland, V. (Coord.). (2007). Repensando a escola: um estudo sobre os desafios de aprender, ler e escrever. Brasília: Ministério da Educação.

Jacquard, A., \& Kahn, A. (2001). 100\% inné, 100\% acquis. In A. Jacquard, A. Kahn. L'avenir n'est pas écrit. Paris: Bayard.

Kampourakis, K., Reydon, T. A., Patrinos, G. P., \& Strasser, B. J. (2014). Genetics and society educating scientifically literate citizens: Introduction to the thematic issue. Science and Education, 23(2), 251-258.

Keller, J. (2005). In genes we trust: The biological component of psychological essentialism and its relationship to mechanisms of motivated social cognition. Journal of Personality and Social Psychology, 88(4), 686.

Luckesi, C. C. (2011). Avaliação da aprendizagem: componente do ato pedagógico. São Paulo: Cortez.

Martinelli, S. D. C., \& Schiavoni, A. (2009). Percepção do aluno sobre sua interação com o professor e status sociométrico. Estudos de Psicologia (Campinas), 26(3), 327-336. http://dx.doi.org/10.1590/S0103$166 \times 2009000300006$

Moore, D. S. (2013). Current thinking about nature and nurture. In D. S. Moore. The philosophy of biology. Amsterdam: Springer.

Osti, A., \& Martinelli, S. D. C. (2014). Desempenho escolar: análise comparativa em função do sexo e percepção dos estudantes. Educação e Pesquisa, 40(1), 49-59.

Pinker, S. (2002). The blank slate: The modern denial of human nature. London: Penguin Books.

Plomin, R., Shakeshaft, N. G., McMillan, A., \& Trzaskowski, M. (2014). Nature, nurture, and expertise.
Intelligence, (45), 46-59. http://dx.doi.org/10.1016/j. intell.2013.06.008

Plomin, R., DeFries, J. C., Knopik, V. S., \& Neiderhiser, J. M. (2016). Top 10 replicated findings from behavioral genetics. Perspectives on Psychological Science, 11(1), 3-23.

Polderman, T. J., Benyamin, B., De Leeuw, C. A., Sullivan, P. F., Van Bochoven, A., Visscher, P. M., \& Posthuma, D. (2015). Meta-analysis of the heritability of human traits based on fifty years of twin studies. Nature Genetics, 47(7), 702-709.

Poropat, A. E. (2009). A meta-analysis of the five-factor model of personality and academic performance. Psychological Bulletin, 135(2), 322-338.

Rattan, A., Savani, K., Naidu, N. V. R., \& Dweck, C. S. (2012). Can everyone become highly intelligent? Cultural differences in and societal consequences of beliefs about the universal potential for intelligence. Journal of Personality and Social Psychology, 103(5), 787.

Ridley M. (2004). O que nos faz humanos. Rio de Janeiro: Record.

Rindermann, H., Becker, D., \& Coyle, T. R. (2016). Survey of expert opinion on intelligence: Causes of international differences in cognitive ability tests. Frontiers in Psychology, 7(339), 1-9.

Snyderman, M., \& Rothman, S. (1988). The IQ controversy, the media and public policy. New Brunswick: Transaction Publishers.

Thomas, A. J., \& Sarnecka, B. W. (2015). Exploring the relation between people's theories of intelligence and beliefs about brain development. Frontiers in Psychology, (6), 1-12. http://dx.doi.org/10.3389/fpsyg. 2015.00921

Tucker-Drob, E. M., \& Briley, D. A. (2014). Continuity of genetic and environmental influences on cognition across the life Span: A meta-analysis of longitudinal twin and adoption studies. Psychological Bulletin, 140(4), 949-979.

Walker, S. O., \& Plomin, R. (2005). The nature-nurture question: Teachers' perceptions of how genes and the environment influence educationally relevant behaviour. Educational Psychology, 25(5), 509-516.

Wesseldijk, L. W., Bartels, M., Vink, J. M., van Beijsterveldt, C. E. M., Lightard, L., Boomsma, D. I., \& Middeldorp, C. M. (2017). Genetic and environmental influences on conduct and antisocial personality problems in childhood, adolescence, and adulthood. European Child \& Adolescent Psychiatry, 26(1), 1-10. http://dx. doi.org/10.1007/s00787-017-1014-y

World Bank Group (2015). World Development Report 2015: Mind, Society, and Behavior. Washington, DC: World Bank.

Received: July 6, 2017

Final version: November 6, 2017

Approved: December 19, 2017 